\title{
GAMBARAN GAYA KEPEMIMPINAN, MOTIVASI KERJA SERTA KINERJA KARYAWAN CIPANAS INDAH HOTEL DI GARUT
}

\author{
Anita Permata Sari \\ Universitas Pendidikan Indonesia \\ permatasanita@gmail.com \\ Hari Mulyadi \\ Universitas Pendidikan Indonesia \\ harimulyadi@upi.edu \\ Eded Tarmedi \\ Universitas Pendidikan Indonesia \\ ededtarmedi@upi.edu
}

\begin{abstract}
ABSTRAK
Tujuan - Tujuan penelitian ini adalah untuk memperoleh gambaran gaya kepemimpinan, memperoleh gambaran motivasi kerja, dan gambaran kinerja karyawan.

Desain/metodologi/pendekatan - Metode yang digunakan adalah Explanatory Survey dengan ukuran sampel sebanya 44 responden. Teknik analisis data yang digunakan adalah regresi linear berganda dengan alat bantu program spss 20.0 for windows.

Temuan - Hasil Penelitian menunjukan bahwa gaya kepemimpinan berada pada kategori efektif, motivasi kerja berada pada kategori kuat dan kinerja karyawan berada pada kategori baik. Gaya kepemimpinan dan motivasi kerja memiliki pengaruh positif terhadap kinerja karyawan.

Orisinalitas/nilai - Penelitian ini memberikan dasar untuk memahami gaya kepemimpinan dan motivasi kerja yang mempengaruhi terhadap kinerja karyawan. Perbedaan penelitian ini dengan penelitian sebelumnya adalah terletak pada objek penelitian yaitu perusahaan Hotel Cipanas Indah dan menggunakan teori atau referensi yang berbeda dengan peneliti sebelumnya.
\end{abstract}

\section{Kata Kunci: Gaya Kepemimpinan, Motivasi Kerja, dan Kinerja Karyawan}

Jenis Artikel: Penelitian

\section{ABSTRACT}

Purpose - This study aimed to gain a sense olqf leadership style, gain a working motivation overview, and overview of employee performance

Design / methodology / approach - The method used is an Explanatory Survey with a sample size of 44 respondents. The data analysis technique used is multiple linear regression with spss 20.0 for windows programming tool.

Findings-Research results show that leadership style is in the category of effective, work motivation is in the strong category and employee performance is in good category. Leadership style and work motivation have a positive influence on employee performance

Originality / value - This study provides a basis for understanding the style of leadership and work motivation that affects employee performance. The difference of this research with previous research is located on the object of research that is Hotel Cipanas Indah company and use theory or reference different from previous researcher

Keywords: Leadership Style, Work Motivation, and Employee Performance

Article Type: Research 


\section{PENDAHULUAN}

Kinerja perusahaan akan sangat dipengaruhi oleh peran dari kinerja karyawan yang berada di dalam perusahaan karena pada hakekatnya perusahaan dijalankan oleh manusia, sama halnya dalam hal strategi bisnis, dalam persaingan bisnis yang semakin ketat ini, perusahaan dapat berhasil jika memiliki keunggulan yang kompetitif yang berkelanjutan. Sumber daya manusia juga merupakan faktor dinamis yang mampu menentukan maju atau mundurnya suatu organisasi (Masharyono \& Sumiyati, 2016). Kemajuan perusahaan ditentukan oleh kualitas sumber daya manusia yang dimlikinya, sehingga sangat penting bagi peusahaan untuk memperhatikan kualitas sumber daya manusia dalam hal ini adalah karyawannya, (Senen \& Siti , 2008). Sumber Daya Manusia (SDM) adalah faktor sentral dalam suatu organisasi. Organisasi dibuat berdasarkan visi untuk kepentingan manusia dan pelaksanaan misimya dikelola dan diatur oleh manusia sebagai sumber daya yang strategi dalam kegiatan institusi maupun organisasi, (Mulyadi, 2010). Berdasarkan hal tersebut semakin jelas bahwa kinerja karyawan sangatlah penting dalam mendukung kemajuan perusaan itu sendiri.

Kinerja karyawan dalam sektor pariwisata dan perhotelan masih banyak yang harus ditingkatkan untuk menunjang kinerja yang baik. Padahal pariwisata merupakan industri jasa yang menjadi katalis ekonomi global dan salah satu alat untuk pembangunan sosial ekonomi diseluruh Dunia, (Wibowo at. al. 2013). Hal ini juga sependapat dengan (Erisha \& Razati, 2016) bahwa pariwisata memiliki dampak secara langsung maupun tidak langsung bagi perekonomian nasional maupun lokal.

Badan Promosi Pariwisata Indonesia (BPPI), Pariwisata Indonesia memiliki banyak permasalahan, salah satunya adalah rendahnya kualitas pelayanan pariwisata serta pertumbuhan dalam pembangunan Hotel tidak diimbangi untuk pengelolaan Hotel secara professional. dengan sumber daya manusia yang berkompeten

(www.travel.detik.com 2017). Kondisi perhotelan pada tahun 2017 masih perlu melakukan sejumlah langkah strategi. Sebab, kondisi saat ini, masih terjadi permasalahan pada bidang tersebut. Oleh karena itu, perlu adanya sinergi yang baik antara pemerintah pusat, provinsi, dan kota/ kabupaten. Wakil Ketua Perhimpunan Hotel dan Restoran Indonesia Sudrajat mengatakan, tingkat okupansi atau hunian hotel di Indonesia selama periode 2016-2017 terus mengalami penurunan. Sudrajat menambahkan, turunnya tingkat hunian hotel tidak sebanding dengan penambahan peningkatan wisatawan serta tidak didukungnya dengan ketersediaan tenaga kerja yang professional (www.bisnis.tempo.co 2017). Hal ini juga terjadi penurunan Tingkat Penghunian Kamar (TPK) Hotel di Jawa Barat. Kepala Badan Pusat Statistik (BPS) Provinsi Jawa Barat, Bachdi Ruswana mengatakan, Tingkat Penghunian Kamar hotel bintang di Jawa Barat pada Januari 2016 sebesar $55,62 \%$, atau turun 3,03 poin dibandingkan Desember 2015 yang tercatat 55,65\%. Tingkat Penghunian Kamar hotel non bintang sebesar $33,42 \%$ turun 2,90 poin dibandingkan Desember 2015 yang tercatat sebesar 36,32\% (www.tribunnewes.com 2017). Perhimpunan Hotel dan Restoran Indonesia (PHRI) Jabar, mengatakan perlu adanya pembenahan pada sejumlah wisata di Jawa Barat. Wisata perlu adanya perhatian dan peningkatan baik itu pelayanannya maupun aksesnya. Menurutnya pembenahan sumber daya manusia sangat diperlukan. Selama kualitas sumber daya manusia masih kurang baik tentu tidak akan berhasil (www.pikiran-rakyat.com 2017).

Salah satu daerah Jawa Barat yaitu Garut, dimana Wisatawan yang berkunjung dan menginap di Kabupaten Garut menurun. Menurunnya Wisatawan mengakibatkan jumlah unit hotel yang sudah dipesan dan dihuni menurun 20\% (www.nasional.republika.co.id 2017). Cipanas Indah Hotel Garut adalah salah satu pariwisata daerah yang ada di Kabupaten Garut yang mengalami penurunan kinerja. Hal ini bisa dilihat dari hasil rekafitulasi penilaian kinerja pada tabel dibawah ini

TABEL 1

REKAPITULASI PENILAIAN KINERJA KARYAWAN CIPANAS INDAH HOTEL DI GARUT 2014-2016

\begin{tabular}{|c|c|c|c|c|c|c|c|c|c|c|c|c|c|}
\hline \multirow{3}{*}{$\begin{array}{l}\text { Penilaian } \\
\text { Prilaku/ } \\
\text { sikap }\end{array}$} & & \multicolumn{12}{|c|}{ Jumlah Penilaian Hasil Kinerja Karyawan dari Banyaknya Karaywan } \\
\hline & & \multicolumn{4}{|c|}{ A } & \multicolumn{2}{|c|}{ B } & \multicolumn{3}{|c|}{$\mathrm{C}$} & \multicolumn{3}{|c|}{ D } \\
\hline & $\begin{array}{l}\text { Jumlah } \\
\text { Karyaw } \\
\text { an }\end{array}$ & 2014 & 2015 & 2016 & 2014 & 2015 & 2016 & 2014 & 2015 & 2016 & 2014 & 2015 & 2016 \\
\hline Kejujuran & \multirow{4}{*}{44} & - & - & - & - & - & - & 42 & 42 & 37 & 2 & 2 & 7 \\
\hline Loyalitas & & - & - & - & - & - & - & 41 & 41 & 42 & 3 & 3 & 2 \\
\hline Keaktifan & & - & - & - & - & - & - & 24 & 28 & 20 & 20 & 16 & 24 \\
\hline Kedisiplinan & & - & - & - & - & - & - & 30 & 28 & 20 & 14 & 16 & 24 \\
\hline
\end{tabular}




\begin{tabular}{|c|c|c|c|c|c|c|c|c|c|c|c|c|}
\hline \multirow{2}{*}{$\begin{array}{l}\text { Penilaian } \\
\text { Prilaku/ } \\
\text { sikap }\end{array}$} & \multicolumn{12}{|c|}{ Jumlah Penilaian Hasil Kinerja Karyawan dari Banyaknya Karaywan } \\
\hline & & $\mathbf{A}$ & & & $\mathbf{B}$ & & & $\mathbf{C}$ & & & D & \\
\hline Kerjasama & - & - & - & - & - & 3 & 27 & 26 & 23 & 17 & 15 & 21 \\
\hline Ketepatan & - & - & - & 4 & 4 & - & 19 & 21 & 15 & 21 & 19 & 29 \\
\hline
\end{tabular}

Sumber: Data intern Hotel Cipanas Indah di Garut (2017)

Dilihat dari Tabel 1 dari indikator kejujuran pada nilai c tahun 2015-2016 mengalami penurunan sebanyak 5 orang, hal ini berdampak terhadap karyawan yang menambah daftar nilai D dari 2 orang menjadi 7 orang. Indikator Loyalitas mengalami perubahan dari tahun 2015-2016 sebanyak 1 orang. Indikator keaktifan pada nilai c tahun 2015-2016 mengalami penurunan, hal ini menambah daftar nilai D sebanyak 8 orang. Indikator Kedisiplinan setiap tahunnya selalu menurun disebabkan bertambahnya nilai D setiap tahaunnya. Begitupun dengan Indikator Kerjasama dan Ketepatan selalu bertambah daftar karyawan yang memiliki nilai D setiap tahunnya. Hal tersebut dapat berdampak pada kunjungan tamu yang menurun, terlihat pada tabel sebagai berikut:

TABEL 2

DATA KUNJUNGAN TAMU DAN KOLAM HOTEL CIPANAS INDAH GARUT 2013-2016

\begin{tabular}{cc}
\hline Tahun & Jumlah (orang) \\
\hline 2013 & 7.818 \\
2014 & 6.071 \\
2015 & 5.340 \\
2016 & 4.570 \\
\hline
\end{tabular}

Sumber: Data Intern Hotel Cipanas Indah di Garut (2017)

Tabel 2 menunjukan bahwa kunjungan tamu yang datang ke Hotel Cipanas Indah Garut selalu mengalami penurunan setiap tahunnya. Kunjungan tamu yang menurun menunjukan kinerja karyawan rendah. Hal ini bisa disebabkan kinerja karyawan yang kurang dalam memberikan pelayanan prima kepada tamu yang datang ke Hotel.

TABEL 3

DATA REALISASI PAD HOTEL DAN KOLAM RENANG CIPANAS INDAH GARUT 2013-2016

\begin{tabular}{cccc}
\hline $\begin{array}{c}\text { Tahu } \\
\mathbf{n}\end{array}$ & $\begin{array}{c}\text { Target } \\
\text { (Rp.) }\end{array}$ & $\begin{array}{c}\text { Realisasi } \\
(\text { Rp. })\end{array}$ & $\begin{array}{c}\text { Persen } \\
(\%) \\
\text { Realisas } \\
\text { i }\end{array}$ \\
\hline 2013 & 250.000 .00 & 235.000 .00 & $94,00 \%$ \\
& 0 & 0 \\
2014 & 316.250 .00 & 151.000 .00 & $47,75 \%$ \\
& 0 & 0 \\
2015 & 221.670 .00 & 70.000 .000 & $31,58 \%$ \\
& 0 & & \\
2016 & 230.000 .00 & 65.000 .000 & $28,26 \%$ \\
& 0 & & \\
\hline
\end{tabular}

Sumber: Data Intern Hotel Cipanas Indah di Garut (2017)
Tabel 3 menunjukan bahwa target dan realisasi di Hotel Cipanas Indah mengalami penurunan setiap tahunnya, dari tahun 2014-2016. Hal ini menunjukan kinerja perusahaan masih rendah.

TABEL 4

REKAPITULASI KEHADIRAN

KARYAWAN CIPANAS INDAH HOTEL DI GARUT TAHUN 2014-2016

\begin{tabular}{ccccc}
\hline $\begin{array}{c}\text { Tah } \\
\text { un }\end{array}$ & $\begin{array}{c}\text { Kehadi } \\
\text { ran } \\
(\%)\end{array}$ & $\begin{array}{c}\text { Ketidakha } \\
\text { diran } \\
(\%)\end{array}$ & $\begin{array}{c}\text { Terla } \\
\text { mbat } \\
\text { Masuk } \\
(\%)\end{array}$ & $\begin{array}{c}\text { Cep } \\
\text { at } \\
\text { Pula } \\
\text { ng }\end{array}$ \\
& & & 17,24 & $\begin{array}{c}24,4 \\
(\%)\end{array}$ \\
\hline 201 & 70,21 & 29,79 & 17,4 \\
4 & & & & 23,1 \\
201 & 64,72 & 35,28 & 14,57 & $\begin{array}{c}23, \\
5\end{array}$ \\
201 & 62,45 & 37,55 & 18,42 & 26,1 \\
6 & & & & 3 \\
\hline
\end{tabular}

Sumber: Data Intern Hotel Cipanas Indah di Garut (2017)

Tabel 4 terlihat bahwa tingkat kehadiran karyawan belum optimal, hal tersebut dapat dilihat tiap tahunnya mengalami kenaikan tingkat ketidakhadiran. Hal tersebut dikarenakan sakit, izin bahkan tanpa keterangan. Kebanyakan karyawan juga banyak yang terlambat masuk kerja serta pulang kerja yang belum waktunya. Ketidaksesuaian kehadiran karyawan sesuai dengan jadwal kerja yang telah ditetapkan mengakibatkan ketidakefisien dan keefektifan dimana akan mempengaruhi waktu kerja dan hasil yang didapatkan dari pekerjaan yang dilakukan.

Kinerja karyawan sangat penting dalam pencapaian tujuan perusahaan. (Sjafri \& Aida, 2007) mengatakan bahwa faktor-faktor yang mempengaruhi kinerja sebagai berikut: a) faktor personal, b) Faktor kepemimpinan, c) Faktor tim, d) Faktor system, e) faktor Kontekstual. Senada dengan pendapat (Mahmudi, 2010) faktor-faktor yang mempengaruhi kinerja antara lain: a) Faktor personal/ individu, b) Faktor kepemimpinan, c) Faktor tim, d) Faktor system dan, e) Faktor konstektual (situasional).

Gaya kepemimpinan adalah salah satu faktor yang dapat mempengaruhi kinerja karyawan. (Uhl-Bien, 2013) menyatakan bahwa kepemimpinan adalah proses mempengaruhi orang lain dan proses memfasilitasi usaha individual dan kolektif untuk menyelesaikan sasaran bersama.. (Sjafri \& Aida, 2007) ketika manajer atau seorang 
pemimpin sudah menentukan gaya kepemimpinan maka keberhasilan untuk menjadi seorang pemimpin dapat diukur dari berbagai segi antara lain, (a) keberhasilan karyawan dan kelompoknya dalam mencapai tujuan organisasi/ perusahaan, (b) kepuasanaan maksimum dikalangan karyawan, (c) drajat maksimum di kalangan karyawan, (c) drajat konflik horizontal dan vertikal yang relatif kecil, (d) perputaran karyawan diantara kelompok pada periode tertentu yang relatif rendah, (e) tingkat ketidakhadiran karyawan relatif rendah, (f) produktivitas kerja karyawan yang meningkat.

Gaya kepemimpinan sangat berpengaruh terhadap kinerja karyawan, (Dharma, 2006). Hal ini sependapat dalam penelitian (Jamaludin, 2017) menyimpulkan bahwa Gaya kepemimpinan berpengaruh positif dan kuat terhadap kinerja karyawan PT Kaho Indah Citra Garment Jakarta. Selain itu (Irmaya, 2017) mengatakan juga bahwa Gaya kepemimpinan berpengaruh positif dan signifikan terhadap kinerja Karyawan Pada PT. Citra Shipyard Batam.

Kinerja karyawan selain dipengaruhi oleh gaya kepemimpinan, dapat dipengaruhi oleh motivasi kerja. (Yoshi, 2017) mengatakan bahwa semakin tinggi motivasi kerja yang diberikan kepada karyawan maka akan semakin tinggi kinerja karyawan tersebut. Motivasi merupakan proses psikologis yang mendasar dan penting dalam bekerja dan merupakan salah satu unsur yang dapat menjelaskan perilaku seseorang.

Tujuan penelitian ini adalah untuk mengetahui gambaran gaya kepemimpinan dan gambaran motivasi kerja yang mempengaruhi kinerja karyawan Cipanas Indah Hotel di Garut.

\section{KAJIAN PUSTAKA}

Kepemimpinan merupakan kunci penggerak kemajuan dalam organisasi atau perusahaan dimana seorang pemimpin mampu mengarhkan bawahannya menjalankan tugas sesuai dengan tujuan yang akan dicapai oleh perusahaan. Gaya kepemimpinan merupakan cara dimana pemimpin menentukan tindakan atau langkah apa yang dapat dilakukan guna mencapai tujuannya. Seperti yang diungkapkan oleh (Thoha, 2012) mengungkapkan gaya kepemimpinan merupakan norma perilaku yang digunakan oleh seseorang pada saat orang tersebut mencoba mempengaruhi perilaku orang lain seperti yang ia lihat. Dalam hal ini usaha menyelaraskan persepsi persepsi diantara orang yang akan mempengaruhi perilaku dengan orang yang akan dipengaruhi menjadi amat penting kedudukannya. Gaya kepemimpinan merupakan sejumlah tindakan dan pengaruh yang didasari oleh alas an dan logika serta inspirasi dan panggilan jiwa.

Gaya kepemimpinan merupakan perilaku atau cara yang dipilih dan digunakan pemimpin dalam mempengaruhi pikiran, perasaan, sikap, dan perilaku organisasi. Sedangkan menurut (Rivai, 2011) gaya kepemimpinan adalah sekumpulan ciri yang digunakan pimpinan mempengaruhi bawahan agar sasaran organisasi tercapai atau dapat pula dikatakan bahwa gaya adalah pola perilaku dan strategi yang disukai dan sering diterapkan oleh seorang pemimpin.

(Dharma, 2006) mengatakan bahwa dimensi gaya kepemimpinan yaitu: 1) Suportive Leader adalah gaya kepemimpinan dimana pemimpin selalu bersedia menjelaskan, mudah didekati dan menunjukkan diri sebagai orang yang sejati bagi bawahan, 2) Delegative leader adalah gaya kepemimpinan dimana pemimpin menyerahkan tanggung jawab atas pelaksanaan pekerjaan pada bawahan, dalam arti pemimpin menginkan agar para bawahan dapat mengendalikan diri mereka sendiri dalam menyelesaikan pekerjaannya, 3) Participative leader adalah gaya kepemimpinan dimana pemimpin selalu meminta dan menggunakan saran-saran bawahan, menciptakan kerjasama yang serasi, menumbuhkan loyalitas dan partisipasi pada bawahan.

Motivasi berasal dari kata latin movere yang berarti dorongan, daya penggerak atau kekuatan yang menyebabkan suatu tindakan atau perbuatan. Kata movere, dalam bahasa Inggris sering disepadankan dengan motivation yang berarti pemberian motif, penimbulan motif, atau hal yang menimbulkan dorongan atau keadaan yang menimbulkan dorongan. Seseorang melakukan suatu tindakan pada umumnya mempunyai suatu motif. Apabila individu tersebut melakukan sesuatu dengan sengaja, tentu ada suatu maksud atau tujuan yang mendorongnya untuk melakukan tindakan tersebut. Motif dasar dari seorang individu pada umumnya adalah adanya kebutuhan akan kebanggan dan kehormatan, serta limpahan materi (Suwatno \& Priansa, 2014).

Motivasi yang dimiliki karyawan dapat meningkatkan kinerja karyawan didalam mencapai tujuan perusahaan itu sendiri. Hal ini sependapat dengan (Yaseen, 2013) mengatakan Motivation is directly linked to performance of employees at work. The motivated employees performance is more apparent than demotivated ones. Artinya motivasi secara langsung terkait dengan kinerja karyawan ditempat kerja. Kinerja karyawan termotivasi lebih jelas daripada yang kehilangan motivasi.

Berdasarkan definisi yang sudah dijelaskan maka dapat diambil kesimpulan bahwa motivasi merupakan kondisi yang ada dalam diri karyawan yang terarah untuk mencapai tujuan organisasi atau perusahaan yang telah ditentukan sebelumnya. Sikap mental karyawan yang pro dan positif terhadap situasi kinerja itulah yang 
memperkuat motivasi kerjanya untuk mencapai kinerja secara optimal.

Tujuan motivasi menurut (Manopo, 2011) mengungkapkan bahwa: 1) Mendorong gairah dan semangat kerja karyawan, 2) Meningkatkan moral dan kepuasan kerja karyawan, 3) Meningkatkan produktivitas kerja karyawan, 4) Mempertahankan loyalitas dan kestabilan karyawan perusahaan, 5) Meningkatkan kedisiplinan dan menurunkan tingkat absensi karyawan, 6) Mengektifkan pengadaan karyawan, 7) Menciptakan kreativitas dan partisipasi karyawan, 8) Menciptakan suasana dan hubungan kerja yang baik, 9) Meningkatkan tingkat kesejahteraan karyawan, 10) Mempertinggi rasa tanggung jawab karyawan terhadap tugas-tugas, 11) Meningkatkan efesiensi penggunaan alat-alat dan bahan baku.

Secara umum dapat dikatakan bahwa tujuan motivasi adalah untuk menggerakan atau mendorong seseorang untuk melakukan sesuatu sehingga dapat memperoleh hasil atau mencapai tujuan tertentu. Semakin jelas tujuan yang diharapkan, maka semakin jelas juga bagaimana tindakan motivasi tersebut dilakukan. Setiap orang yang akan memberikan motivasi harus memahami betul tentang latar belakang kehidupan, kebutuhan, dan kepribadian orang yang akan dimotivasi.

(Firdawati, 2017) mengatakan Perusahaan perlu melakukan pemahaman atas apa yang dibutuhkan atau keinginan oleh karyawan dimana indikator tersebut yaitu, 1) rasa layak dan cukup, 2) rasa dihargai dan dihormati, 3) rasa aman, 4) hubungan yang baik, 5) rasa adil dan ada kesempatan, 6) rasa senang, 7) rasa kebebasan dan nyaman. (Fisbach dan Choi 2012) dalam bukunya dimensi motivasi kerja terdiri dari 1) Accessibility and inhibition of goal-related constructs, 2) Evaluation and devaluation, 3) Experience, 4) Perseptual bases, 5) Behavioral measures, 6) Speed, 7) Performance, 8) Choice.

Kinerja merupakan suatu fungsi dari motivasi dan kemampuan. Untuk menyelesaikan tugas atau pekerjaan seseorang sepatutnya memiliki derajat kesediaan dan tingkat kemampuan tertentu. Kesediaan dan keterampilan seseorang tidaklah cukup efektif untuk mengerjakan sesuatu tanpa permasalahan yang jelas tentang apa yang akan dikerjakan sesuatu tanpa pemahaman yang jelas tentang apa yang akan dikerjakan dan bagaimana mengerjakannya. Kinerja merupakan perilaku nyata yang ditampilkan setiap orang sebagai prestasi kerja yang dihasilkan oleh pegawai sesuai dengan perannya dalam perusahaan (Rivai \& Jauvani, 2009).

Kinerja karyawan merupakan suatu hal yang sangat penting dalam upaya untuk mencapai tujuannya. (Torang, 2012) yang menyatakan bahwa, kinerja adalah kuantitas dan atau kualitas hasil kerja individu atau sekelompok didalam organisasi dalam melaksanakan tugas pokok dan fungsi yang berpedoman pada norma, standar operasional prosedur, kriteria dan ukuran yang telah ditetapkan atau yang berlaku dalam organisasi.

Kinerja karyawan dipengaruhi oleh faktor instrinsik dan ektrinsik. Faktor-faktor intrinsik yang mempengaruhi kinerja karyawan terdiri dari pendidikan, pengalaman, motivasi, kesehatan, usia, keterampilan, emosi, dan spiritual. Sedangkan faktor ektrinsik yang mempengaruhi kinerja karyawan terdiri dari lingkungan fisik dan non fisik, kepemimpinan, komunikasi vertikal dan horizontal, kompensasi, kontrol berupa penyeliaan, fasilitas, pelatihan, beban kerja, prosedur kerja, system hukuman dan sebagainya (Sjafri \& Aida, 2007). Lebih lanjut (Sjafri \& Aida, 2007) menguraikan faktor-faktor tersebut sebagai berikut: a) faktor personal, faktor personal karyawan meliputi unsur pengetahuan, keterampilan, kemampuan, kepercayaan diri, motivasi dan komitmen yang dimiliki setiap individu, b) Faktor kepemimpinan, meliputi aspek kualitas manajer dan team leader dalam memberikan dorongan, semangat, arahan, dan dukungan kerja kepada karyawan, c) Faktor tim, meliputi kualitas dukungan dan semangat yang diberikan oleh rekan dalam suatu team, d) Faktor system, meliputi system kerja, fasilitas kerja dan instrakstruktur yang diberikan oleh organisasi, kompensasi dan proses organisasi dan kultur kinerja dalam organisasi, e) faktor Kontekstual, meliputi tekanan dan perubahan lingkungan eksternal dan internal.

\section{METODE PENELITIAN}

Berdasarkan pada variabel-variabel yang akan diteliti maka jenis penelitian yang dilakukan berdasarkan penjelasan dan bidang penelitian menggunakan penelitian deskriptif dan verifikatif. Menurut (Maholtra, 2013) menjelaskan bahwa penelitian deskriptif adalah jenis penelitian konklusif yang mempunyai tujuan utama menggambarkan sesuatu apa adanya sesuai karakteristik objek. Penelitian yang bersifat deskriptif ini bertujuan untuk mengetahui gambaran mengenai pengaruh gaya kepemimpinan dan motivasi kerja terhadap kinerja karyawan Cipanas Indah Hotel di Garut.

Sedangkan penelitian verifikatif menurut (Toto \& Nanang, 2012) mengemukakan bahwa penelitian verifikatif (pembuktian) yaitu penelitian yang dilakukan dengan tujuan menguji kebenaran dan hasil penelitian yang telah dilakukan sebelumnya. Dalam penelitian verifikatif bermaksud untuk mengetahui pengaruh gaya 
kepemimpinan dan motivasi kerja terhadap kinerja karyawan Cipanas Indah Hotel di Garut.

Berdasarkan jenis penelitian tersebut, maka metode yang digunakan adalah explanatory survei bertujuan untuk mengetahui hubungan antar variabel dengan cara pengujian hipotesis. (Toto \& Nanang, 2012) mengemukakan bahwa, Penelitian survei yaitu penelitian yang dilakukan dengan maksud mengetahui sesuatu secara keseluruhan dari wilayah atau objek penelitian.

Sampel yang digunakan dalam penelitian ini didapat dengan pengambilan sampel atau teknik sampling non probability sampling, dengan pengambilan sampling jenuh. Peneliti menggunakan teknik sampling jenuh karena jumlah populasi kurang dari 100 orang. Sampling jenuh adalah teknik pengambilan sampel apabila semua populasi digunakan sebagai sampel dan dikenal juga dengan istilah sensus (Riduwan, 2012).

Sumber data yang digunakan adalah sumber data primer (primary data source) dan sumber data sekunder (secondary data sources). Data primer yaitu data yang diperoleh peneliti secara langsung, diperoleh dari tangan pertama dengan tujuan untuk menjawab permasalahan dalam penelitian. Dalam penelitian ini yang menjadi sumber data primer adalah kuesioner yang disebarkan kepada sejumlah responden, sesuai dengan target sasaran dan dianggap mewakili seluruh populasi data penelitian, yakni 44 responden pada karyawan Cipanas Indah Hotel Garut. Data sekunder yaitu data yang diperoleh secara tidak langsung, yang telah dikumpulkan oleh peneliti yang tersedia di sumber publikasi dan non publikasi yang berguna bagi peneliti. Dalam penelitian ini yang menjadi sumber data sekunder yaitu, artikel, jurnal serta situs di internet yang $\mathbf{1 5 2 4}$

\begin{tabular}{|l|c|c|c|c|}
$\begin{array}{c}\text { Sangat Tidak } \\
\text { Efektif }\end{array}$ & $\begin{array}{c}\text { Tidak } \\
\text { Efektif }\end{array}$ & $\begin{array}{c}\text { Cukup tidak } \\
\text { efektif }\end{array}$ & Efektif & Sangat Efektif \\
\hline $\mathbf{3 9 6}$ & $\mathbf{7 1 3}$ & $\mathbf{1 0 3 0}$ & $\mathbf{1 3 4 7}$ & $\mathbf{1 6 6 4}$
\end{tabular}

GAMBAR 1

HASIL KONTINUM GAYA KEPEMIMPINAN

Secara ideal skor yang diharapkan untuk jawaban karyawan Cipanas Indah Hotel terhadap penyataan 1-9 adalah 1980. Berdasarkan perhitungan diatas menunjukan nilai yang diperoleh adalah sebesar 1980 atau persentasenya sebesar 76,96\% dari skor ideal yaitu 1980, dengan demikian gaya kepemimpinan berada pada kategori efektif.

TABEL 5

REKAPITULASI INDIKATOR DARI GAYA KEPEMIMPINAN berkenaan dengan penelitian yang mampu merperlihatkan permasalahan.

Penelitian ini menganalisis lebih dari dua variabel, maka digunakan teknik analisis regresi linear ganda. Analisis regresi linear berganda digunakan oleh peneliti bila peneliti bermaksud meramalkan keadaan (naik turunnya) variabel dependent, bila dua atau lebih variabel independent sebagai faktor prediktor dimanipulasi.

Sebagai langkah terakhir dari analisis data adalah pengujian hipotesis. Untuk menguji hipotesis yang telah dirumuskan harus menggunakan uji statistik yang tepat. Hipotesis penelitian akan diuji dengan mendeskripsikan hasil analisis regresi linear ganda. Untuk uji global regresi dilakukan dengan uji F. Sedangkan Uji keberatian koefisien regresi dilakukan melalui uji $\mathrm{t}$ dengan cara membandingkan antara $t_{\text {hitung dengan }}$ $t_{\text {tabel }}$ dari koefisien regresi tiap variabel indipenden. Uji $\mathrm{t}$ bertujuan untuk mengetahui apakah koefisien regresi dari tiap variabel independen memiliki pengaruh yang berarti terhadap variabel dependen.

\section{HASIL PENELITIAN DAN PEMBAHASAN Gambaran Gaya Kepemimpinan}

Hasil pengolahan data yang telah dilakukan melalui penyebaran kuesioner pada karyawan Cipanas Indah Hotel, dapat diukur melalui perhitungan skor dimensi gaya kepemimpinan. Skor total dimensi gaya kepemimpinan sebesar 1524 sedangkan skor idealnya adalah 1980. Hal ini menunjukan bahwa pelaksanaan gaya kepemimpinan Cipanas Indah Hotel sudah efektif. Jumlah skor tersebut dimasukan dalam garis kontinum sebagai berikut:

\begin{tabular}{ccccc}
\hline $\mathbf{N}$ & Dimensi & $\begin{array}{c}\text { Peroleha } \\
\text { n Skor }\end{array}$ & $\begin{array}{c}\text { Skor } \\
\text { Idea } \\
\text { I }\end{array}$ & $(\mathbf{\% )}$ \\
\hline 1 & $\begin{array}{l}\text { Supportive } \\
\text { Leader } \\
2\end{array}$ & 523 & 660 & 79,3 \\
$\begin{array}{l}\text { Delegative } \\
\text { Leader } \\
\text { Participativ } \\
\text { e leader }\end{array}$ & 526 & 660 & 79,7 \\
\hline & Total Skor & $\mathbf{1 5 2 4}$ & $\mathbf{1 9 8 0}$ & $\begin{array}{c}\mathbf{7 6 , 9} \\
\mathbf{6}\end{array}$ \\
\hline
\end{tabular}

Sumber : Hasil Pengolahan Data, 2018 
Berdasarkan hasil penelitian dari kuesioner yang disebar kepada 44 responden. Skor yang terdapat pada dimensi gaya kepemimpinan yaitu Supportive leader di peroleh skor 523 atau sebesar 79,3\%, delegative leader diperoleh skor 526 yaitu sebesar 79,7\%, participative leader dengan skor 475 atau sebesar 71,9\%. Dapat diketahui bahwa gaya kepemimpinan pada karyawan Cipanas Indah Hotel mencapai skor 1524 yaitu sebesar 76,96\% dan skor kriterium atau jumlah maksimal perolehan nilai responden terletak pada daerah kriterium efektif yaitu pada interval 1347-1664.

Gaya kepemimpinan merupakan norma perilaku yang digunakan seseorang pada saat orang tersebut mencoba mempengaruhi perilaku orang lain. Dalam hal ini usaha menyelaraskan perilaku dengan orang yang akan mempengaruhi perilaku dengan orang perilakunya akan dipengerahui menjadi amat penting kedudukannya, (Rivai, 2009). Gaya kepemimpinan dapat dikatakan baik jika kepemimpinan tersebut dapat diterapkan oleh seorang pemimpin dengan baik dan diterima oleh karyawan yang ada di perusahaan tersebut sehingga kinerja karyawan tersebut dapat ditingkatkan. Apabila kinerja karyawan dapat dijalankan dengan baik maka hal ini akan berdampak baik pada pencapaian tujuan perusahaan. Oleh karena itu gaya kepemimpinan sangat berperan penting dan perlu diperhatikan oleh seorang pemimpin. Dengan gaya kepemimipinan yang sesuai maka seorang pemimpin harus dapat berkomunikasi dengan baik dapat bekerja sama dalam hal tugas dan tanggung jawab.

Kinerja karyawan dipengaruhi secara positif oleh gaya kepemimpinan. Hal tersebut sesuai dengan Menurut temuan (Sri 2012) menyebutkan bahwa gaya kepemimpinan ada kaitanya terhadap kinerja karyawan. Atasan yang baik, berwibawa, penuh perhatian, dapat membimbing dan mengarahkan anak buahnya dan dapat meningkatkan kinerja karyawan. Dengan gaya kepemimpinan yang sesuai maka seorang pemimpin harus dapat berkomunikasi dengan baik dan dapat bekerja sama dalam hal tugas dan tanggung jawab. Menurut (Tampubolon, 2007) telah meneliti pengaruh gaya kepemimpinan terhadap kinerja, menyatakan bahwa gaya kepemimpinan mempunyai pengaruh yang signifikan terhadap kinerja karyawan.

\section{Gambaran Motivasi Kerja}

Hasil pengolahan data mengenai motivasi kerja terlihat pada gambar 2 berikut ini:

1736

\begin{tabular}{|l|l|l|ll|l|} 
Sangat tidak kuat & Tidak Kuat & Cukup tidak kuat & Kuat & Sangat Kuat \\
\hline $\mathbf{4 4 0}$ & $\mathbf{7 9 2}$ & $\mathbf{1 1 4 4}$ & $\mathbf{1 4 9 6}$ & $\mathbf{1 8 4 8}$
\end{tabular}

GAMBAR 3

HASIL KONTINUM MOTIVASI KERJA

Berdasarkan hasil penelitian dari kuesioner yang disebar kepada 44 responden dapat diketahui bahwa perhitungan diatas menunjukan nilai yang diperoleh adalah sebesar 1736 atau sebesar $78,9 \%$ dari skor ideal 2200, dengan demikian motivasi kerja berada pada kategori kuat.

TABEL 6

REKAPITULASI INDIKATOR DARI MOTIVASI KERJA

\begin{tabular}{llccc}
\hline No & Dimensi & $\begin{array}{c}\text { Perolehan } \\
\text { Skor }\end{array}$ & $\begin{array}{c}\text { Skor } \\
\text { Ideal }\end{array}$ & $\mathbf{( \% )}$ \\
\hline 1 & $\begin{array}{l}\text { Kebutuhan } \\
\text { Fisiologis }\end{array}$ & 356 & 440 & 80,9 \\
2 & $\begin{array}{l}\text { Keselamatan } \\
\text { dan }\end{array}$ & 343 & 440 & 77,9 \\
& $\begin{array}{l}\text { Kesehatan } \\
\text { Kerja } \\
\text { Kebutuhan } \\
\text { rasa }\end{array}$ & 343 & 440 & 77,9 \\
\hline
\end{tabular}

\begin{tabular}{llccc}
\hline No & Dimensi & $\begin{array}{c}\text { Perolehan } \\
\text { Skor }\end{array}$ & $\begin{array}{c}\text { Skor } \\
\text { Ideal }\end{array}$ & $(\%)$ \\
\hline & $\begin{array}{l}\text { memiliki } \\
\text { pada } \\
\text { pekerjaan } \\
\text { dan pada } \\
\text { perusahaan }\end{array}$ & & & \\
4 & $\begin{array}{l}\text { Kebutuhan } \\
\text { harga diri } \\
\text { Kebutuhan } \\
\text { aktualisasi } \\
\text { diri }\end{array}$ & 342 & 440 & 77,7 \\
\hline & & 440 & 80 \\
Total Skor & $\mathbf{1 7 3 6}$ & $\mathbf{2 2 0 0}$ & $\mathbf{7 8 , 9}$ \\
\hline
\end{tabular}

Sumber : Hasil Pengolahan Data, 2018

Berdasarkan hasil penelitian dari kuesioner yang disebar kepada 44 responden karyawan dapat diketahui bahwa dimensi motivasi kerja yang terdiri dari kebutuhan fisiologis diperoleh skor 356 atau sebesar 80,9\%, Keselamatan dan Kesehatan Kerja diperoleh skor 
343 atau sebesar $77,9 \%$, kebutuhan rasa memiliki pada pekerjaan dan pada perusahaan diperoleh 343 atau sebesar 77,9\%, kebutuhan harga diri diperoleh skor 342 atau sebesar $77,7 \%$, dan kebutuhan aktualisasi diri diperoleh skor 352 atau sebesar 80\%. Motivasi Kerja karyawan Cipanas Hotel Indah mencapai skor 1736 atau sebesar 78,9\%,dari skor kriterium atau jumlah maksimal perolehan nilai responden terletak pada daerah kriterium tinggi yaitu pada interval 1496-1848. Dalam hal ini perusahaan perlu meningkatkan lagi pada dimensi kebutuhan harga diri, karena memiliki skor terendah. Sebagaimana menurut (Maslow, 2009) mengatakan bahwa kebutuhan harga diri merupakan penghargaan dari orang lain. Dalam hal ini individu butuh penghargaan atas apa-apa yang dilakukannya disini individu akan berusaha memenuhi kebutuhan akan harga diri, apabila kebutuhan akan rasa cinta dan rasa memilikinya telah terpenuhi atau terpuaskan. Setiap orang menginginkan penghargaan yang positif. Penghargaan yang positif akan membuat seseorang merasa berharga, berhasil, dan berguna. Terpenuhinya kebutuhan harga diri akan menghasilkan sikap optimis dan percaya diri. Apabila kebutuhan harga diri tidak terpenuhi, maka akan membuat seseorang berprilaku negative, (Ghufron, 2010). Menurut (Mubarak \& Chayatin, 2008) didalam hirarki kebutuhan maslow memiliki delapan macam kebutuhan yaitu: a) kebutuhan oksigen dan petukaran gas, b) kebutuhan cairan dan elektrolit, c) kebutuhan makanan, d) kebutuhan eliminasi urine, e)

2566 kebutuhan istirahat dan tidur, f) kebutuhan aktivitas, g) kebutuhan sexsual.

Motivasi kerja merupakan hal yang sangat penting untuk diperhatikan oleh perusahaan jika menginginkan setiap karyawan dapat memberikan kontriusi positif terhadap pencapaian tujuan perusahaan. Dengan tidak adanya motivasi, sesorang karyawan tidak dapat bekerja sesuai standar perusahaan yang telah diterapkan, karena yang menjadi motif atau motivasi dalam diri karyawan tidak terpenuhi. Walaupun karyawan tersebut memiliki kemampuan yang sangat baik tetapi tidak memiliki motivasi yang tinggi dalam bekerja maka hasilnyapun tidak sesuai dengan apa yang diharapkan perusahaan. Mereka akan menganggap bahwa motifasi dalam dirinya telah hilang karena tidak terpenuhinya kebutuhan hidup.

Seorang karyawan akan bersedia melakukan upaya yang lebih besar apabila diyakini bahwa upaya itu akan berakibat pada penilaian kinerja yang baik dan bahwa penilaian kinerja yang baik akan berakibat pada imbalan yang lebih besar dari organisasi, seperti bonus yang lebih besar, kenaikan gaji, serta promosi dan kesemuanya itu memungkinkan yang bersangkutan untuk mencapai tujuan pribadinya Victor dalam (Mangkunegara, 2011). Berdasarkan hasil penelitian yang bersifat empiris bahwa Kinerja karyawan dipengaruhi oleh motivasi kerja.

\section{Gambaran Kinerja Karyawan}

Hasil pengolahan data mengenai kinerja karyawan terlihat pada gambar 4 berikut ini:

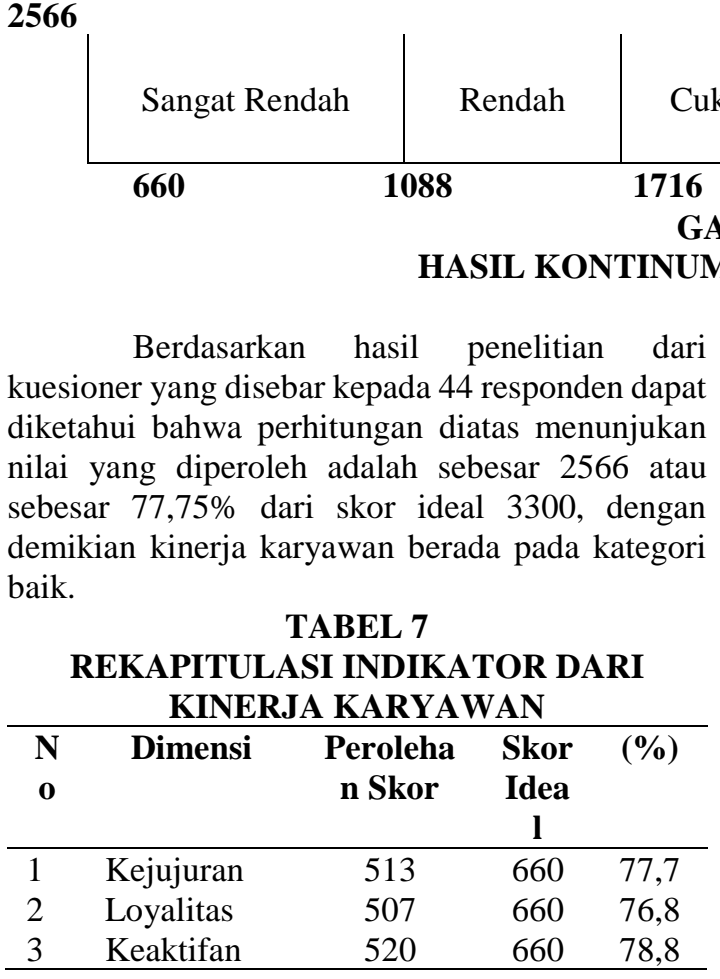

GAMBAR 4

\begin{tabular}{|c|c|c|c|c|}
\hline kup Rendah & Baik & \multicolumn{3}{|c|}{ Sangat Baik } \\
\hline $\begin{array}{l}\text { AMBAR } 4 \\
\text { I KINERJA }\end{array}$ & $\begin{array}{l}2244 \\
\text { KARYAWAI }\end{array}$ & & & \\
\hline 4 & $\begin{array}{l}\text { Kedisiplina } \\
\mathrm{n}\end{array}$ & 339 & 440 & 77 \\
\hline 5 & Kerjasama & 342 & 440 & 77,7 \\
\hline 6 & Ketepatan & 345 & 440 & 78,4 \\
\hline & Total Skor & 2566 & 3300 & $\begin{array}{c}77,7 \\
5\end{array}$ \\
\hline
\end{tabular}

Sumber : Hasil Pengolahan Data, 2018

Berdasarkan hasil penelitian dari kuesioner yang dimana pimpinan menilai 44 responden karyawan dapat diketahui bahwa dimensi Kinerja karyawan yang terdiri dari kejujuran diperoleh skor 513 atau sebesar 77,7\%, Loyalitas diperoleh skor 507 atau sebesar 76,8\%, Keaktifan diperoleh skor 520 atau sebesar 78,8\%, kedisiplinan diperoleh skor 339 atau sebesar $77 \%$, kerjasama diperoleh skor 342 atau sebesar 77,7\% dan ketepatan diperoleh skor 345 atau sebesar 
78,75\%. Kinerja karyawan Cipanas Hotel Indah mencapai skor 2566 atau sebesar $77,75 \%$, dari skor kriterium atau jumlah maksimal perolehan nilai responden terletak pada daerah kriterium baik yaitu pada interval 2244-2772.

Dimensi loyalitas memiliki skor terendah dari pada dimensi yang lainnya. Menurut (Jusuf, 2010) terdapat beberapa faktor yang dapat mempengaruhi loyalitas karyawan, yaitu: a) faktor rasional, yang menyangkut hal-hal yang bisa dijelaskan secara logis seperti gaji, bonus, jenjang karir, dan fasilitas-fasilitas yang diberikan perusahaan, b) faktor Emosional, yaitu menyangkut perasaan atau ekspresi diri seperti pekerjaan yang menantang, lingkungan kerja yang mendukung, perasaan aman karena perusahaan merupakan tempat kerja dalam jangka panjang, pemimpin berkaharisma, pekerjaan yang membagakan, penghargaan-penghargaan yang diberikan perusahaan dan budaya kerja, c) faktor kepribadian, yaitu menyangku sifat, karakter, tempramen yang dimiliki oleh karyawan. Dalam hal ini, perusahaan mempunyai tujuan yakni memeberikan pelayanan yang baik kepada karyawan. Tinggi rendahnya kinerja yang dimiliki karyawan yang ada dalam perusahaan dipengerahui beberapa faktor penting. Faktorfaktor tersebut bisa berasal dari luar ataupun dari dalam diri karyawan karyawan tersebut salah satunya dapat dilihat dari loyalitas karyawan terhadap perusahaan.

Loyalitas dapat diartikan dengan kesetiaan, pengabdian, dan kepercayaan yang diberikan kepada seseorang atau perusahaan (Aldrianto, 2016). Jadi loyalitas biasanya dilihat dari masa kerja yang lama pada perusahaan, maka bisa dibilang semakin lama masa kerja pada perusahaan semakin tinggi loyalitas pada perusahaan. Namun loyalitas tidak hanya dilihat dari masa kerja, tetapi dapat diukur melalui beberapa faktor seperti kedisiplinan yang tinggi, bekerja dengan baik, bertanggungjawab pada pekerjaan dan keterlibatan karyawan dalam menyelesaikan permasalahn pada sebuah pekerjaan. Oleh karena itu, perusahaan juga harus mampu memperhatikan loyalitas karyawannya karena menjadi faktor penting terhadap peningkatan kinerja.

(Rivai \& Jauvani, 2009) menyatakan bahwa, kinerja merupakan suatu fungsi dari motivasi dan kemampuan. untuk menyelesaikan tugas atau pekerjaan seseorang sepatutnya memiliki derajat kesediaan dan tingkat kemampuan tertentu. Kesediaan dan keterampilan seseorang tidaklah cukup efektif untuk mengerjakan sesuatu tanpa permasalahan yang jelas tentang apa yang akan dikerjakan sesuatu tanpa pemahaman yang jelas tentang apa yang akan dikerjakan dan bagaimana mengerjakannya. Sedangkan (Sedarmayanti, 2011) mendefinisikan bahwa kinerja merupakan gambaran tingkat pencapaian pelaksanaan program kegiatan/kebijakan dalam mewujudkan sasaran, tujuan, visi, dan misi organisasi yang dituangkan melalui perencanaan strategis suatu oragnisasi.

Selain itu untuk mengetahui analisis regresi linear berganda menggunakan program SPSS 20.0 for Windows, diperoleh hasil koefisien regresi sebagai berikut:

\section{TABEL 8}

MODEL REGRESI LINEAR BERGANDA

GAYA KEPEMIMPINAN DAN MOTIVASI KERJA TERHADAP KINERJA KARYAWAN Coefficients $^{\mathrm{a}}$

\begin{tabular}{|c|c|c|c|c|c|c|c|c|}
\hline \multirow{2}{*}{\multicolumn{2}{|c|}{ Model }} & \multicolumn{2}{|c|}{$\begin{array}{c}\text { Unstandardized } \\
\text { Coefficients }\end{array}$} & $\begin{array}{l}\text { Standardized } \\
\text { Coefficients }\end{array}$ & \multirow[t]{2}{*}{$\mathrm{T}$} & \multirow[t]{2}{*}{ Sig. } & \multicolumn{2}{|c|}{ Collinearity Statistics } \\
\hline & & B & Std. Error & Beta & & & Tolerance & VIF \\
\hline \multirow{3}{*}{1} & (Constant) & 66,830 & 12,388 & & 5,395 & 000 & & \\
\hline & Gaya Kepemimpinan &,- 035 & ,233 &,- 023 &,- 149 & ,882 & ,979 & 1,022 \\
\hline & Motivasi Kerja & $-1,86$ & 210 &,- 138 &,- 886 & ,381 & ,979 & 1,022 \\
\hline
\end{tabular}

a. Dependent Variable: Kinerja Karyawan

Sumber: Hasil Pengolahan Data 2017

Dari Tabel 8 mengenai koefisien regresi, maka diperoleh persamaan regresi linear berganda antara gaya kepemimpinan dan motivasi kerja terhadap kinerja karyawan, yaitu sebagai berikut: $\mathrm{Y}=66,830+(-0,35) \mathrm{X}_{1}+(-1,86) \mathrm{X}_{2}$

Berdasarkan persamaan regresi linear berganda di atas, nilai konstanta 66,830 menunjukan bahwa jika tidak ada gaya kepemimpinan dan motivasi kerja, maka besarnya kinerja karyawan sebesar 66,830. Koefisien regresi $-0,35$ satu satuan nilai artinya setiap terjadi peningkatan gaya kepemimpinan akan meningkatkan kinerja karyawan sebesar -0,35 satu satuan nilai dan sebaliknya jika terjadi penurunan gaya kepemimpinan, kinerja karyawan akan menurun sebesar $-0,35$ satu satuan nilai. Sedangkan koefisien regresi $-1,86$ satu satuan nilai artinya setiap terjadi peningkatan motivasi kerja akan meningkatkan kinerja karyawan sebesar 1,86 satu satuan nilai dan sebaliknya jika terjadi 
penurunan kinerja karyawan, motivasi kerja akan menurunkan kinerja karyawan -1,86 satu satuan nilai. Selanjutnya tabel 9 hasil output Koefisien determinasi sebagai berikut:

\begin{tabular}{|l|l|l|l|l|l|}
\hline Model & $\mathrm{R}$ & $\mathrm{R}$ Square & $\begin{array}{l}\text { Adjusted } \\
\text { Square }\end{array}$ & $\begin{array}{l}\text { Std. Error of the } \\
\text { Estimate }\end{array}$ & Durbin-Watson \\
\hline 1 &, $961^{\mathrm{a}}$ &, 923 &, 921 & 1,93212 & 2,206 \\
\hline
\end{tabular}

a. Predictors: (Constant), gaya kepemimpinan, motivasi kerja

b. Dependent Variable: kinerja karyawan Sumber: Hasil Pengolahan Data, 2018

Berikut adalah hasil perhitungan koefisien determinasi $X_{1}, X_{2}$, dan Y:

KD $X_{1}$ dan $X_{2}$ terhadap $\mathrm{Y}=r^{2}$ x $100 \%=(0,137)^{2}$ $\mathrm{x} 100=\%$

Berikut adalah hasil perhitungan koefisien determinasi $X_{1}, X_{2}$, dan Y:

KD $X_{1}$ dan $X_{2}$ terhadap $Y=r^{2}$ x $100 \%=(0,961)^{2}$ $\mathrm{x} 100=92,3 \%$

Koefisien determinasi untuk gaya kepemimpinan $\left(X_{1}\right)$ dan motivasi kerja $\left(X_{2}\right)$ terhadap kinerja karyawan $(Y)$ adalah $92,3 \%$. Dengan kata lain kinerja karyawan dipengaruhi 92,3\% oleh gaya kepemimpinan dan motivasi kerja, sedangkan 7,7\% dipengaruhi oleh faktorfaktor lainnya yang tidak diteliti dalam penelitian ini.

Adapun besarnya pengaruh secara parsial antara masing-masing variabel yaitu gaya kepemimpinan terhadap kinerja karyawan mempunyai pengaruh sebesar $90,8 \%$ artinya kinerja karyawan dipengaruhi gaya kepemimpinan sebesar 90,8\% dan sisanya 9,2\% dipengaruhi oleh faktor lainnya yang tidak diteliti dalam penelitian ini. Motivasi kerja terhadap kinerja karyawan mempunyai pengaruh sebesar $83,4 \%$ yang artinya kinerja karyawan dipengaruhi motivasi kerja sebesar 83,4\% dan sisanya $16,6 \%$ dipengaruhi oleh faktor lain. Dapat kita lihat pada Gambar 5

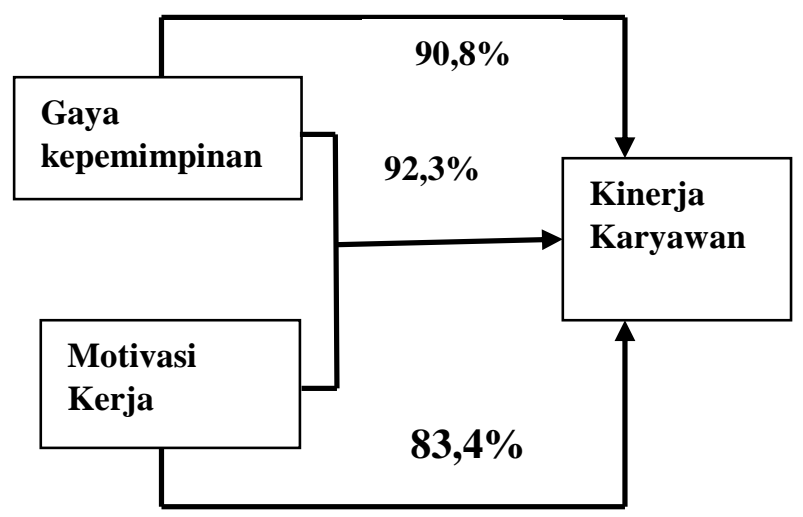

\section{GAMBAR 5} KOEFISIEN DETERMINASI

Untuk menguji signifikansi pengaruh gaya kepemimpinan dan motivasi kerja terhadap kinerja karyawan dapat digunakan uji F. Rumus uji F dijelaskan pada Tabel 10 berikut ini:

TABEL 10

NILAI SIGNIFIKANSI UJI FANOVA ${ }^{a}$

ANOVA $^{\mathrm{a}}$

\begin{tabular}{|rl|r|r|r|r|r|}
\hline Model & & Sum of Squares & Df & Mean Square & F & Sig. \\
\hline \multirow{2}{*}{1} & Regression & 70,025 & 2 & 35,013 & 3,635 &, $035^{\mathrm{b}}$ \\
& Residual & 394,952 & 41 & 9,635 & & \\
& Total & 464,977 & 43 & & & \\
\hline
\end{tabular}

a. Dependent Variable: Kinerja Karyawan

b. Predictors: (Constant), Motivasi Kerja, Gaya Kepemimpinan

Sumber: Hasil Pengolahan Data, 2018

Tabel 10 menunjukkan pengujian untuk uji $\mathrm{F}$ yang diambil dari Anova dengan tingkat probabilitas $(S i g)=0,035$, maka taraf signifikan 0,05 yaitu $0,035 \leq 0,05$. maka keputusan adalah $\mathrm{H}_{\mathrm{o}}$ ditolak. Artinya terdapat pengaruh yang positif antara pengaruh gaya kepemimpinan dan motivasi kerja terhadap kinerja karyawan Cipanas Indah Hotel.
Peneliti juga melakukan pengujian pengaruh variabel bebas secara bersama-sama terhadap variabel terikat dengan menggunakan uji F yaitu $F_{\text {hitung }}>F_{\text {tabel }}$. Maka $F_{\text {tabel }}$ dengan 44 responden yaitu pada $\mathrm{a}=0,05$ adalah 3,209. Sehingga didapat 3,635>3,209, maka $\mathrm{H}_{\mathrm{o}}$ ditolak. Sehingga dapat dikatakan bahwa gaya 
kepemimpinan dan motivasi kerja berpengaruh bersama-sama terhadap kinerja karyawan.

Dengan demikian dapat disimpulkan bahwa hipotesis dalam penelitian ini yaitu $H_{o}$ ditolak dan $\mathrm{H}_{\mathrm{a}}$ diterima, sehingga:

1. Terdapat pengaruh positif dari gaya kepemimpinan terhadap kinerja karyawan Cipanas Indah Hotel

2. Terdapat pengaruh positif dari motivasi kerja terhadap kinerja karyawan Cipanas Indah Hotel.

3. Terdapat pengaruh positif dari gaya kepemimpinan dan motivasi kerja terhadap kinerja karyawan Cipanas Indah Hotel

\section{KESIMPULAN DAN REKOMENDASI}

Berdasarkan pembahasan maka dapat disimpulkan sebagai berikut:

1. Hampir seluruh tanggapan karyawan tentang gaya kepemimpinan sudah efektif. Hal ini dapat dilihat dari dimensi yang tertinggi ke yang terendah yaitu, 1) Delegative Leader, 2) Supportive Leader, 3) Participative Leader.

2. Hampir seluruh tanggapan karyawan tentang motivasi kerja sudah kuat. Hal ini dapat dilihat dari dimensi yang tertinggi ke yang terendah yaitu, 1) Kebutuhan fisiologis, 2) Kebutuhan aktualisasi diri, 3) Keselamatan dan Kesehatan kerja, 4) Kebutuhan rasa memiliki pada pekerjaan dan perusahaan, 5) Kebutuhan harga diri.

3. Hampir seluruh tanggapan pimpinan tentang kinerja karyawan sudah baik. Hal ini dapat dilihat dari dimensi yang tertinggi ke yang terendah yaitu, 1) Keaktifan, 2) ketepatan, 3) kejujuran, 4) kerjasama, 5) kedisiplinan, 6) Loyalitas.

4. Gaya kepemimpinan berpengaruh positif terhadap kinerja karyawan. Hal ini menunjukan semakin efektif gaya kepemimpinan yang digunakan seorang pimpinan maka akan efektif pula terhadap kinerja karyawan.

5. Motivasi kerja mempunyai pengaruh positif terhadap kinerja karyawan. Hal ini menunjukan semakin kuat motivasi kerja yang dimiliki karyawan maka akan meningkatkan kinerja karyawan didalam bekerja.

6. Gaya kepemimpinan dan motivasi kerja samasama mempunyai pengaruh yang positif terhadap kinerja karyawan. Dengan adanya gaya kepemimpinan yang efektif dan motivasi kerja yang kuat maka dapat mengakibatkan meningkatnya kinerja karyawan, dimana hal tersebut dapat tercapainya tujuan perusahaan.

Berdasarkan kesimpulan diatas maka dapat direkomendasikan sebagai berikut:

1. Gaya kepemimpinan pada dimensi Participative Leader memiliki skor terendah maka peneliti merekomendasikan agar perusahaan memperhatikan kebutuhan apa saja yang diinginkan karyawan seperti memberikan penghargaan kepada karyawan dalam bekerja, memberikan gaji yang sesuai dengan hasil kerja, memberikan rasa aman, serta pimpinan mampu memberikan dukungan moral kepada karyawan dalam bekerja. Dengan terpenuhi kebutuhan karyawan maka akan tercipta loyalitas karyawan dalam bekerja.

2. Motivasi Kerja pada dimensi kebutuhan harga diri memiliki skor terendah maka peneliti merekomendasikan perusahaan untuk memberikan apresiasi atau penghargaan kepada karyawan dalam bekerja, memberikan kepercayaan kepada karyawan untuk melakukan tugasnya dengan baik. Dengan terpenuhinya kebutuhan harga diri, maka karyawan akan merasa dihargai dan dipercayai didalam bekerja sehingga motivasi kerja karyawan akan kuat yang menimbulkan kinerja karyawan baik.

3. Kinerja Karyawa pada dimensi loyalitas memiliki skor terendah maka peneliti merekomendasikan perusahan memberikan gaji yang sesuai dengan hasil kerja, adanya bonus dan jenjang karir, serta memberikan perasaan aman ditempat kerja dalam jangka panjang.

4. Hasil penelitian menyatakan bahwa gaya kepemimpinan berpengaruh positif terhadap kinerja karyawan, maka peneliti merekomendasikan agar pimpinan bisa menciptakan gaya kepemimpinan yang mampu meningkatkan kinerja karyawan dalam bekerja. Gaya kepemimpinan yang mampu berkomunikasi baik dengan karywan, serta mampu menciptakan suasana yang serasi dengan karyawan.

5. Hasil penelitian menyatakan bahwa motivasi kerja berpengaruh positif terhadap kinerja karyawan, maka peneliti merekomendasikan agar perusahan terus memperbaiki dan meningkatkan motivasi kerja di perusahaan, dengan memiliki motivasi kerja yang selalu tinggi dalam diri karyawan maka akan tinggi pula kinerja karyawan tersebut.

6. Hasil penelitian menyatakan bahwa gaya kepemimpinan dan motivasi kerja berpengaruh secara positif terhadap kinerja karyawan, maka peneliti merekomendasikan agar perusahaan menjaga dan meningkatkan gaya kepemimpinan dan motivasi kerja yang sudah terbentuk demi terpeliharanya kinerja karyawan yang tinggi pada perusahaan.

7. Diharapkan penelitian ini dapat membantu kepada peneliti berikutnya dalam melakukan penelitian mengenai gaya kepemimpinan dan 
motivasi kerja dengan indikator serta objek yang berbeda dan adanya tambahan pada teori-teori yang digunakan.

\section{DAFTAR PUSTAKA}

A.A.Anwar Prabu Mangkunegara. (2011). Manajemen Sumber Daya Manusia Perusahaan. PT.Remaja Rosda Karya, Bandung

Abraham, Maslow. (2009). Manajemen Sumber Daya Manusia. Jakarta: PT. Elek Media Koptindo

Aldrianto, Muhammdad. (2016) Skripsi Pengaruh Disiplin Kerja dan Loyalitas Terhadap Kinerja Karyawan Pada PT Kospermindo di Makassar. Fakultas Ekonomi dan Bisnis Universitas Hasanuddin: Makassar

Amstrong, Michael. 2012. Amstrong's handbook of Human Resorce Management Practice $12^{\text {th }}$ edition. United Kingdom: Kogan Page Limited.

Anitah, Sri. 2012. Media Pembelajaran. Surakarta: Yuma Pustaka

Anwar, Jusuf. 2010. Pasar Modal sebagai sarana pembiaayaan dan investasi. Bandung : PT. Alumni

Arikunto, Suharsimi. 2010. Prosedur Penelitian Suatu Pendekatan Praktis. Yogyakarta: Bima Aksara.

Coulter, Stephen P. Robbins and Mary. 2012. Management, Eleventh Edition, Alih Bahasa: Bob Sabran. Jakarta: Erlangga.

Danang, Suyonto. 2012. Teori, Kuiseoner, dan Analisis Data Sumber Daya Manusia. Jakarta: PT. buku Seru.

Dharma, A., (2006). Manajemen Supervisi. Jakarta: Raja Grafindo Persada.

Erisha, Mia \& Razati Girang. (2016). Pengaruh Kinerja People dan Physical Evidence terhadap Keputusan Menginap Survei terhadap Tamu Hotel Kampung Sumber Alam Garut. Journal of Business Management Education; 1 (2). 17-24

Fridawati, Agnes Widya. (2017). Faktor-faktor yang Mempengaruhi Motivasi, Kompensasi, Kerja terhadap Kinerja Karyawan. Inovasi; 19 (1).

Ghufron. (2010). Teori-teori Psikologi. Jogjakarta: Ar-Ruzz Media

Hughes, dkk. (2012). Leadership: Memperkaya Pelajaran dari Pengalaman, edisi 7. Jakarta: Salemba Humanika

Husein,Umar. (2008). Metode Penelitian Untuk Skripsi dan Tesis Bisnis. Jakarta. PT Rajagrafindo Persada

Irmaya, Ade at.al. (2017). Pengaruh Gaya Kepemimpinan, Motivasi, dan Kepuasan Kerja Terhadap Kinerja
Karyawan pada PT. Citra Shipy ARD Batam. Jurnal Bening Prodi Manajemen Universitas Riau Kepulauan Batam; 4 (2). Print ISSN: 2252-52672

Jamaludin, Agus. (2017). Pengaruh Gaya Kepemimpinan terhadap Kinerja Karyawan pada PT. Kaho Indah Citra Garment Jakarta. Journal of Applied usiness and Economics; 3 (3). 161-169

Wibowo, Lili Adi, at. all. (2013). Pengaruh Brand Feelings terhadap Loyalitas Tamu di Sheraton Senggigi Beach Resort Lombok. The Journal; III (2). Hal: 607

Mahmudi. 2010. Manajemen Kinerja Sektor Publik, Edisi ke-2. Yogyakarta: YKPN

Manopo, C. 2011. Competency Based Talent and Performance Management System. Salemba Emapat Jakarta.

Mubarak \& Chayatin. (2008). Buku Ajar Kebutuhan Dasar Manusia Teori dan Aplikasi dalam Praktik, Jakarta : Penerbit Buku Kedokteran EGC

Mulyadi, Hari. (2010). Pengaruh Motivasi dan Kompetensi Kerja Terhadap Produktivitas Kerja Karyawan pada Pt. Galamedia Bandung Perkasa. Manajerial; 9 (17). 97-111

Perti, H.L \& Govern, J.M. 2013. Motivation: Theory, Reaseacrh and Aplication. Wadsworth/ Thomson, Inc

Riduwan. (2012). Belajar Mudah Penelitian Untuk Guru, Karyawan, Peneliti Pemula. Bandung: Alfabeta

Rivai, Veithzal. (2009). Manajemen Sumber Daya Manusia Untuk Perusahaan Dari Teori ke Praktik. Jakarta: Raja Grafindo Persada

Rivai, Veithzal. (2011). Manajemen Sumber Daya Manusia. Jakarta.

Rivai, Veitzal \& Jauvani, Ella. (2009). Manajemen Sumber Daya Manusia untuk Perusahaan. Edisi Kedua, Jakarta: Penerbit PT. Raja Grafindo Persada.

Robbins,Stephen P. and Coulter,Mary. 2012. Management. New Jersey: Pearson Education, Inc.

Sedarmayanti. 2011. Sumber Daya Manusia dan Produktivitas Kerja. Bandung: Mandar Maju

Sjafri Mangkuprawira dan aida vitaliya hubeis. 2007. Manajemen mutu sumber daya manusia. Ciawi bogor. Penerbit Ghalia Indonesia.

Suwatno dan Donni Juni Priansa. (2014). Manajemen SDM dalam Organisasi 
Publik dan Bisnis, Penerbit Bandung: Bandung

Syamsir Torang. 2012. Metode Riset Struktur \& Perilaku Organisasi. Bandung: Alfabeta.

Syamsul Hadi Senen. Syamsul. Masharyono. Nida Triananda. Sumiyati. (2016). The Employee Performance Influenced by Communication: a Study of BUMD in Indonesia. Indonesia

Syamsul Hadi Senen, Siti Solihat. (2008). Pengaruh MotivasiKerja dan Kemampuan Kerja Karyawan terhadap Produktivitas Kerja Karyawan pada PT. Safilindo Permata. Jurnal Strategic; 7 (14)

Tampubolon, Biatna. D. 2007. Analisis Faktor Gaya Kepemimpinan Dan Faktor Etos Kerja Terhadap Kinerja Pegawai Pada Organisasi Yang Telah Menerapkan SNI 19-9001-2001. Jurnal Standardisasi. No 9. Hal: 106115.

Thoha, Miftah. 2012. Perilaku Organisasi Konsep Dasar dan Aplikasinya. Jakarta: Rajawali Pers.

Uhl-Bien, Mary. 2013. Organizational Behavior $13^{\text {th }}$ Edition. New Jersey: John Wiley \& Sons, Inc.

Yaseen, Somia. 2013. Factors Affecting the Performance of Employees at Work Place in the Banking Sector of Pakistan. Middle-East Journal of Scientific Reseacrh; 17(9). pp.1208 ISSN 1990-9233

Yaseen, Somia. 2013. Factors Affecting the Performance of Employees at Work Place in the Banking Sector of Pakistan. Middle-East Journal of Scientific Reseacrh; 17 (9) pp.1208 ISSN 1990-9233

Yoshi, Tania. (2017). Pengaruh Gaya Kepemimpinan Transformasional dan Motivasi Kerja Terhadap Kinerja Karyawan pada PT. Premier Management Consulting. Agora; 5 (1).

www.bisnis.tempo.co

www.pikiran-rakyat.com

www.nasional.republika.co.id 